ARTICLE

Received 1 Apr 2015 | Accepted 8 Nov 2015 | Published 16 Dec $2015 \quad$ DOl: 10.1038/ncomms10155 OPEN

\title{
The impact of disturbed peatlands on river outgassing in Southeast Asia
}

\author{
Francisca Wit ${ }^{1}$, Denise Müller ${ }^{1,2}$, Antje Baum¹, Thorsten Warneke ${ }^{2}$, Widodo Setiyo Pranowo ${ }^{3}$, Moritz Müller ${ }^{4}$ \\ \& Tim Rixen ${ }^{1,5}$
}

River outgassing has proven to be an integral part of the carbon cycle. In Southeast Asia, river outgassing quantities are uncertain due to lack of measured data. Here we investigate six rivers in Indonesia and Malaysia, during five expeditions. $\mathrm{CO}_{2}$ fluxes from Southeast Asian rivers amount to $66.9 \pm 15.7 \mathrm{Tg} C$ per year, of which Indonesia releases $53.9 \pm 12.4 \mathrm{Tg} C$ per year. Malaysian rivers emit $6.2 \pm 1.6 \mathrm{Tg} C$ per year. These moderate values show that Southeast Asia is not the river outgassing hotspot as would be expected from the carbonenriched peat soils. This is due to the relatively short residence time of dissolved organic carbon (DOC) in the river, as the peatlands, being the primary source of DOC, are located near the coast. Limitation of bacterial production, due to low $\mathrm{pH}$, oxygen depletion or the refractory nature of $\mathrm{DOC}$, potentially also contributes to moderate $\mathrm{CO}_{2}$ fluxes as this decelerates decomposition.

\footnotetext{
${ }^{1}$ Leibniz Center for Tropical Marine Ecology (ZMT), Fahrenheitstrasse 6, 28359 Bremen, Germany. ${ }^{2}$ Institute for Environmental Physics, University of Bremen, Otto-Hahn-Allee 1, 28359 Bremen, Germany. ${ }^{3}$ Research \& Development Center for Marine \& Coastal Resources (P3SDLP), Gedung II Balitbang KP Lantai 4 Jalan Pasir Putih II, Ancol Timur, Jakarta 14430, Indonesia. ${ }^{4}$ Swinburne University of Technology, Sarawak Campus, Jalan Simpang Tiga, Kuching, Sarawak 93350, Malaysia. ${ }^{5}$ Institute of Geology, University of Hamburg, Bundesstrasse 55, 20146 Hamburg, Germany. Correspondence and requests for materials should be addressed to F.W. (email: francisca.wit@leibniz-zmt.de).
} 
T he importance of inland waters in the global carbon cycle has gained more awareness since the last decade through studies which have revealed that inland waters (rivers, streams, lakes, reservoirs and estuaries) are not a passive conduit but play an integral role both for carbon storage and greenhouse gas emissions to the atmosphere ${ }^{1-4}$. These studies estimate, in line with the 5th Assessment IPCC Report ${ }^{5}$, that on a global scale $\sim 45-60 \%$ (0.9-1.4 PgC per year) of carbon entering the freshwater system is decomposed and emitted back to the atmosphere as $\mathrm{CO}_{2}$. Another $0.2-0.6 \mathrm{PgC}$ per year is buried in freshwater sediments and about $0.9 \mathrm{Pg} \mathrm{C}^{1}$ reaches the coastal ocean. However, an estimate of inland water outgassing by Raymond et al. ${ }^{6}$ revealed an emission of $2.1 \mathrm{PgC}$ per year, of which $1.8 \mathrm{PgC}$ per year from streams and rivers, which is significantly larger than previous estimates. On the other hand, a more recent study by Lauerwald et al. ${ }^{7}$ estimates a global river outgassing of $0.65 \mathrm{PgC}$ per year, however, they have excluded stream orders $<2$. These variable findings challenge our current understanding of the global carbon cycle and in particular that of the terrestrial biosphere as a sink for anthropogenic $\mathrm{CO}_{2}$. Still, large uncertainties remain in outgassing fluxes due to scarcity of data, which we aim to resolve for Southeast (SE) Asia. Indonesia and Malaysia are areas of particular interest due to their peatlands, which together store $66.5 \mathrm{PgC}$ (ref. 8). It has been shown recently that the fluvial organic carbon flux increases once these tropical peatlands are disturbed ${ }^{9}$. However, it remains unclear to what extent this influences the $\mathrm{CO}_{2}$ emissions from these aquatic systems.

In this study, river outgassing fluxes are quantified for SE-Asia by using measurements from four rivers in Sumatra, Indonesia, and two rivers in Sarawak, Malaysia (Fig. 1). $\mathrm{CO}_{2}$ fluxes and yields for all rivers are determined and related to peat coverage, which uncovers a positive relationship. Based on this correlation, $\mathrm{CO}_{2}$ fluxes for SE-Asia are calculated, which reveal moderate fluxes and show that SE-Asia is not a hotspot for river outgassing.

\section{Results}

River processes and variability. In estuaries, salinities higher than zero can be measured $18-50 \mathrm{~km}$ downstream with increasing salinities towards the coastal ocean (Fig. 2a), whereas $\mathrm{pCO}_{2}$ concentrations show an opposite pattern with increasing concentrations going upstream (Fig. 2c). Indeed, in the estuaries, salinity is inversely correlated with $\mathrm{CO}_{2}$ concentrations (Fig. 2b) as a consequence of mixing between river and oceanic waters and the associated decrease of $\mathrm{pH}$ in rivers. To calculate mean river parameter values, estuaries were excluded to avoid the influence from ocean waters and only data points with salinity $0-0.1$ in the respective rivers were taken into consideration (Fig. 2d, Table 1).

Figure $2 \mathrm{~d}$ shows the variability of the $\mathrm{pCO}_{2}$ data in the Sumatran rivers in 2009 and 2013. The highest $\mathrm{pCO}_{2}$ concentrations were measured in the Siak river, which also reveals the highest dissolved organic carbon (DOC) and the lowest $\mathrm{O}_{2}$ concentrations (Table 1, Fig. 3). This agrees with results derived from numerical model and DOC decomposition experiments, which show that DOC leaching from peat soils and the decomposition of its labile fraction are the main factors controlling DOC and $\mathrm{O}_{2}$ concentrations in the Siak ${ }^{10}$. The resulting input of dissolved inorganic carbon and the already low $\mathrm{pH}$, caused by the organic acids from peat, shift the carbonate system $\left(\mathrm{CO}_{2} \Leftrightarrow \mathrm{HCO}_{3}^{-} \Leftrightarrow \mathrm{CO}_{3}^{2-}\right)$ towards $\mathrm{CO}_{2}$ and explain the high $\mathrm{CO}_{2}$ concentrations in the Siak. Increasing $\mathrm{pCO}_{2}$ concentrations associated with increasing DOC concentrations denote that DOC leaching and decomposition are prime factors controlling $\mathrm{pCO}_{2}$ concentrations also in all other studied rivers (Fig. 3).

Contrary to the Siak, which is a typical black-water river where its dark brown colour reduces light penetration to a few centimeters, non-black-water rivers have a higher light availability. Accordingly, photosynthesis plays a role and therefore these rivers have a pronounced day and night cycle, as seen in the Musi river during our expedition in 2013. As we entered this river during the day the $\mathrm{pCO}_{2}$ concentrations were lower than during the departure, which took place during the night when photosynthesis and $\mathrm{CO}_{2}$ uptake could not take place, but decomposition and $\mathrm{CO}_{2}$ production prevailed. In total, the observed variability of $\mathrm{pCO}_{2}$ in the Musi was $\pm 21.5 \%$, which was reduced to $\pm 6.2 \%$ in the Siak due to a reduced impact of photosynthesis in peat-draining rivers.

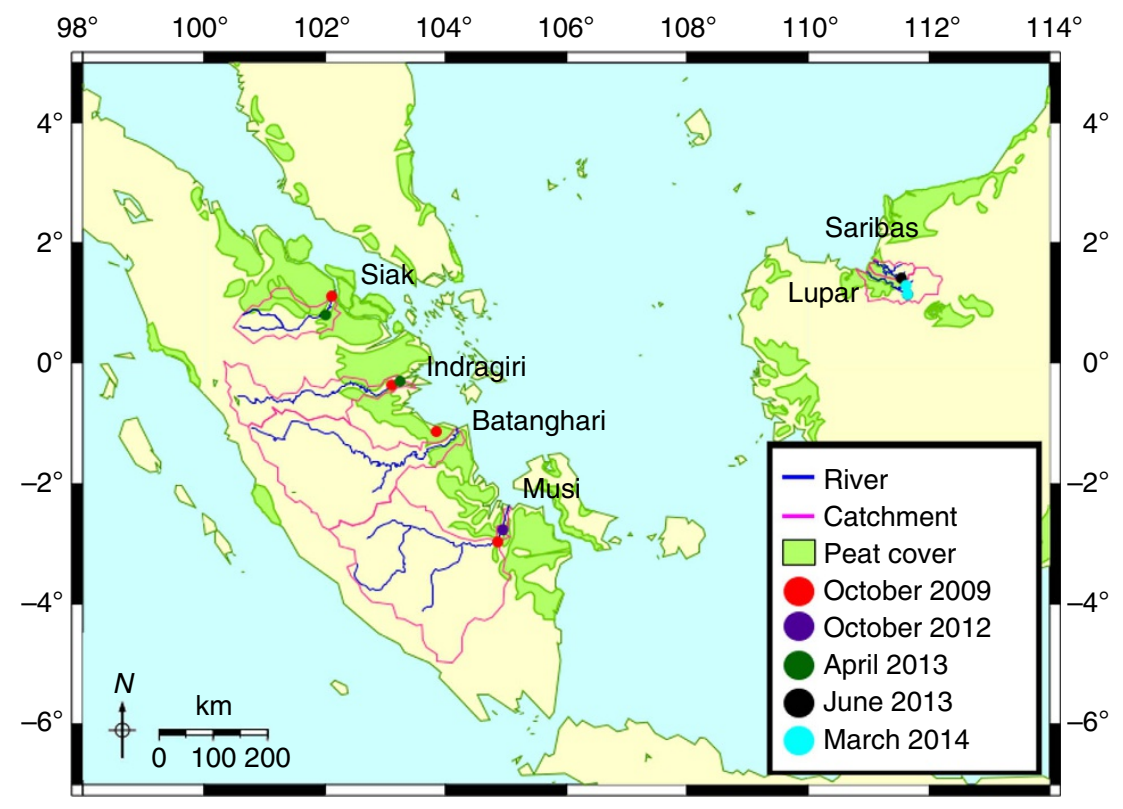

Figure 1 | Study area and rivers in Indonesia and Malaysia. The data points indicate the zero-salinity locations in each river, from which the parameter values were averaged. 
a

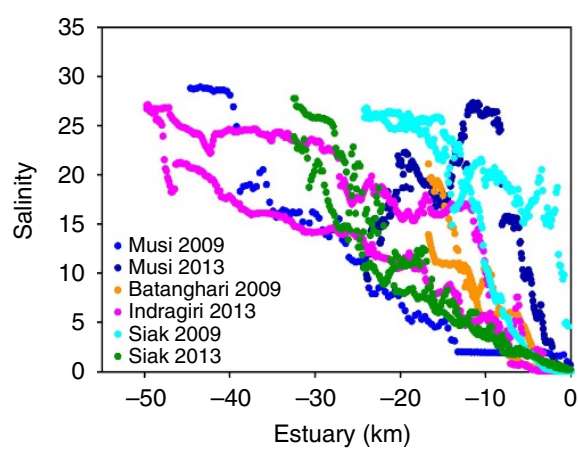

C

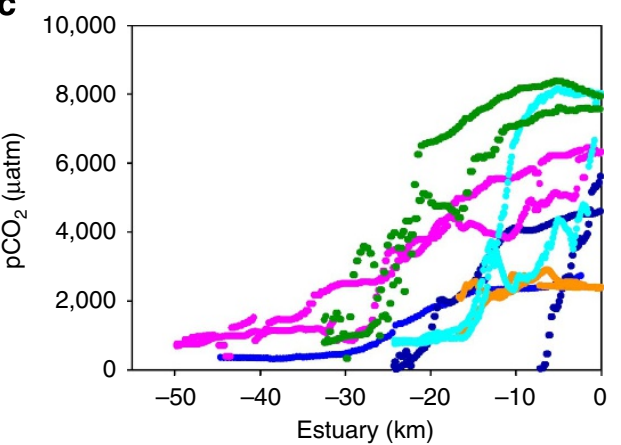

b

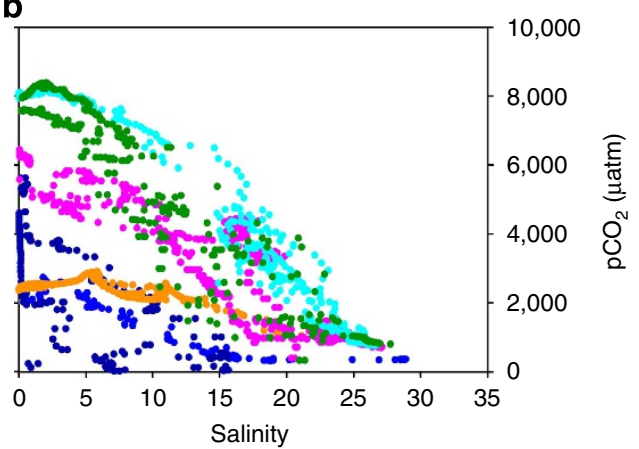

d

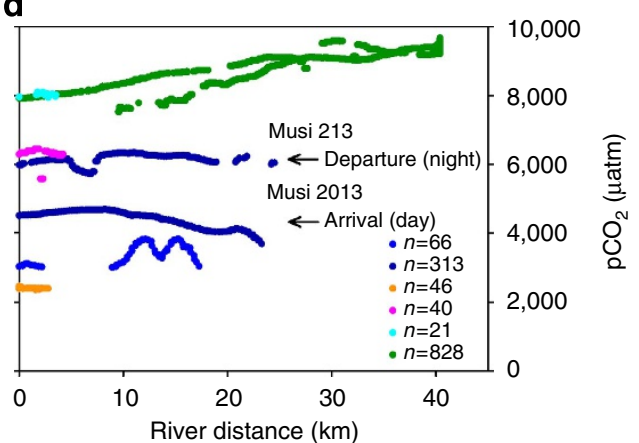

Figure 2 | Patterns of salinity and $\mathrm{pCO}_{2}$ underway measurements on the way in and out of the estuaries and rivers in 2009 and 2013. Estuaries start at $0 \mathrm{~km}$, which is the border with the river at salinity zero, with increasing (negative) distance towards the coastal ocean. Measurements in the rivers start at $0 \mathrm{~km}$ at salinity $<0.1$ with increasing distance upstream. (a) Decrease of salinity across estuary towards river. (b) Inverse relationship of pCO $\mathrm{C}_{2}$ versus salinity (>0.1). (c) Increase of $\mathrm{pCO}_{2}$ across estuary towards river. (d) $\mathrm{pCO}_{2}$ data points at zero salinity (0-0.1) against river distance, with number of data points in the lower right corner.

Table 1 | Averaged parameters per river and year.

\begin{tabular}{|c|c|c|c|c|c|c|c|}
\hline River & Time & $\mathrm{pCO}_{2}$ ( $\left.\mu \mathrm{atm}\right)$ & DOC $\left(\mu \mathrm{moll}^{-1}\right)$ & $\mathrm{O}_{2}\left(\mu \mathrm{mol} \mathrm{I}^{-1}\right)$ & Temperature $\left({ }^{\circ} \mathrm{C}\right)$ & pH (-) & Precipitation $^{\star}(\mathrm{mm})$ \\
\hline \multirow[t]{4}{*}{ Musi } & October 2009 & $3,388 \pm 294$ & $223.3 \pm 4.5$ & $158.4 \pm 24.9$ & $30.8 \pm 0.11$ & - & $197 \pm 50$ \\
\hline & October 2012 & - & $264.5 \pm 5.3$ & $137.1 \pm 48.3$ & $31.4 \pm 0.09$ & $6.86 \pm 0.25$ & $249 \pm 63$ \\
\hline & April 2013 & $5,244 \pm 892$ & - & $152.8 \pm 55.9$ & $29.7 \pm 0.57$ & - & $238 \pm 61$ \\
\hline & Average & $4,316 \pm 928$ & $243.9 \pm 20.6$ & $149.4 \pm 6.4$ & $30.6 \pm 0.50$ & $6.86 \pm 0.25$ & $228 \pm 34$ \\
\hline \multirow[t]{4}{*}{ Batanghari } & October 2009 & $2,400 \pm 18$ & $363.0 \pm 2.7$ & $162.8 \pm 1.3$ & $29.8 \pm 0.08$ & $7.07 \pm 0.01$ & $180 \pm 46$ \\
\hline & October 2012 & - & $286.9 \pm 2.8$ & - & $29.5 \pm 0.05$ & - & $293 \pm 75$ \\
\hline & April 2013 & - & $314.2 \pm 5.1$ & - & $30.8 \pm 0.05$ & - & $252 \pm 64$ \\
\hline & Average & $2,400 \pm 18$ & $321.4 \pm 22.6$ & $162.8 \pm 1.3$ & $29.8 \pm 0.39$ & $7.07 \pm 0.01$ & $242 \pm 72$ \\
\hline \multirow[t]{3}{*}{ Indragiri } & October 2009 & $5,275 \pm 0$ & $774 \pm 5.1$ & $128.4 \pm 0$ & $29.8 \pm 0.00$ & - & $227 \pm 58$ \\
\hline & April 2013 & $6,278 \pm 206$ & $651.1 \pm 4.5$ & $69.4 \pm 4.0$ & $32.3 \pm 0.13$ & $6.30 \pm 0.05$ & $332 \pm 85$ \\
\hline & Average & $5,777 \pm 527$ & $712.6 \pm 61.5$ & $98.9 \pm 29.5$ & $31.1 \pm 1.25$ & $6.30 \pm 0.05$ & $280 \pm 93$ \\
\hline \multirow[t]{8}{*}{ Siak } & March $2004^{\dagger}$ & - & $1,866 \pm-$ & - & - & - & - \\
\hline & September $2004^{\dagger}$ & - & $2,195 \pm-$ & - & - & - & - \\
\hline & August $2005^{\dagger}$ & - & $2,247 \pm-$ & - & - & - & - \\
\hline & March $2006^{\dagger}$ & - & $1,613 \pm-$ & - & - & - & - \\
\hline & November $2006^{\dagger}$ & - & $1,793 \pm-$ & - & - & - & - \\
\hline & October 2009 & $8,027 \pm 40$ & $2,453.0 \pm 49.1$ & $17.1 \pm 1.2$ & $29.8 \pm 0.00$ & $4.78 \pm 0.03$ & $318 \pm 81$ \\
\hline & April 2013 & $9,083 \pm 567$ & $636.1 \pm 3.9$ & $35.3 \pm 18.3$ & $30.1 \pm 0.57$ & $5.48 \pm 0.20$ & $206 \pm 67$ \\
\hline & Average & $8,555 \pm 528$ & $1,829.0 \pm 245.6$ & $26.2 \pm 9.1$ & $30.0 \pm 0.15$ & $5.13 \pm 0.48$ & $262 \pm 79$ \\
\hline \multirow[t]{3}{*}{ Lupar } & June 2013 & $1,527 \pm 38$ & $88.5 \pm 1.8$ & $161.3 \pm 0.8$ & $29.0 \pm 0.05$ & $6.70 \pm-$ & $88 \pm 22$ \\
\hline & March 2014 & $1,021 \pm 357$ & $207.9 \pm 1.1$ & $180.1 \pm 0.9$ & $28.4 \pm 0.05$ & $7.10 \pm 0.34$ & $167 \pm 43$ \\
\hline & Average & $1,274 \pm 148$ & $148.2 \pm 59.7$ & $170.7 \pm 9.4$ & $28.7 \pm 0.30$ & $6.90 \pm 0.28$ & $128 \pm 70$ \\
\hline \multirow[t]{2}{*}{ Saribas } & June 2013 & $1,159 \pm 29$ & $312.2 \pm 1.3$ & $121.2 \pm 0.6$ & $29.2 \pm 0.05$ & $7.30 \pm-$ & $88 \pm 22$ \\
\hline & & $1,159 \pm 29$ & $312.2 \pm 1.3$ & $121.2 \pm 0.6$ & $29.2 \pm 0.05$ & $7.30 \pm-$ & $88 \pm 22$ \\
\hline
\end{tabular}


The Musi also shows an interannual variability with lower $\mathrm{pCO}_{2}$ concentrations in 2009 as compared with 2013 due to lower precipitation rates and lower DOC leaching.

Although this supports our former finding that DOC leaching is a prime factor controlling $\mathrm{pCO}_{2}$ concentrations, there are also exceptions, which point to other processes, as indicated by the high $\mathrm{pCO}_{2}$ but low DOC concentrations in the Siak in 2013.
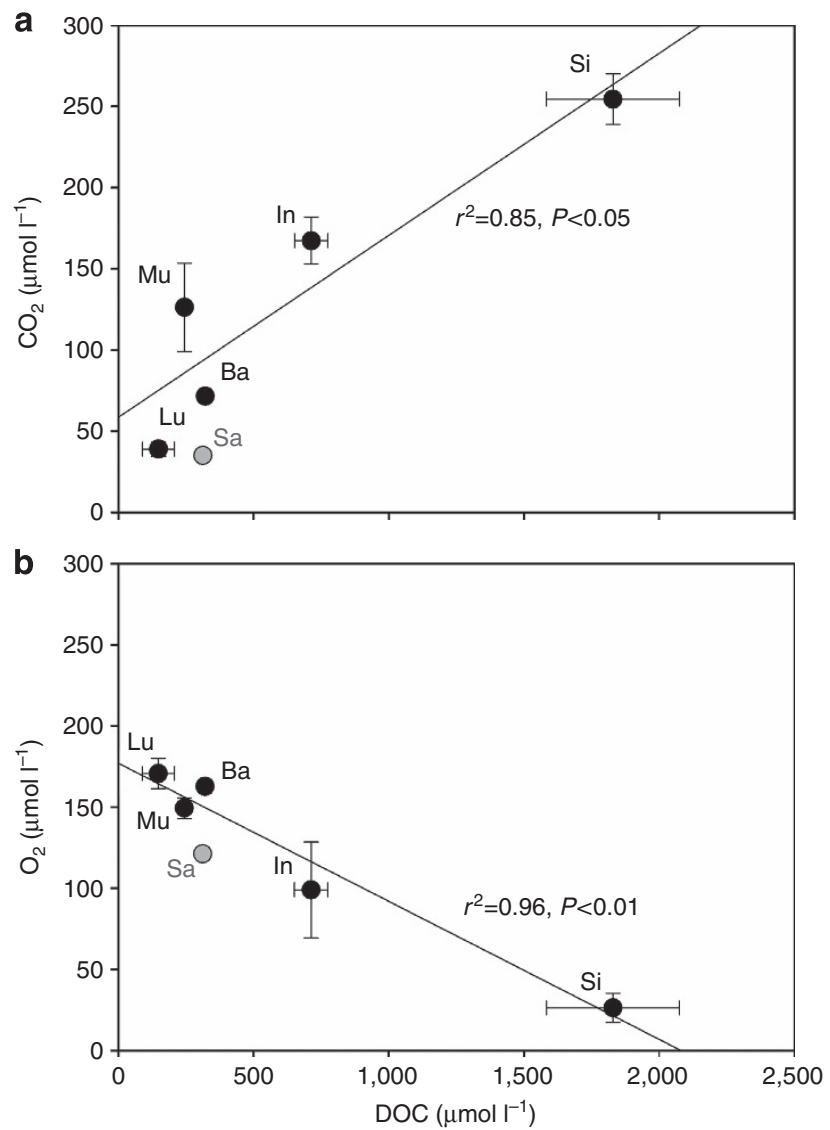

Figure 3 | Linear correlations of $\mathrm{CO}_{\mathbf{2}}$ and $\mathrm{O}_{\mathbf{2}}$ versus DOC. (a) Correlation of $\mathrm{CO}_{2}$ versus DOC. (b) Correlation of $\mathrm{O}_{2}$ versus DOC. All values are in $\mu \mathrm{moll} \mathrm{I}^{-1}$. The data points represent annual averages in the Musi, Batanghari, Indragiri and Siak rivers in Sumatra (Indonesia) and the Lupar and Saribas rivers in Sarawak (Malaysia). The Saribas, having only one (seasonal) data point, was excluded from the correlation and is shown in grey. Error bars mean \pm s.d.
Contrary to non-peat-draining rivers, enhanced discharge lowers DOC concentrations in rivers draining undisturbed peat. This reverse behaviour is caused by the high water saturation of peat due to which enhanced precipitation leads to flooding and the resulting surface runoff increases discharge, which dilutes the DOC concentrations in the peat-draining rivers ${ }^{11-13}$. However, the peatlands in the Siak catchment as well as elsewhere in Indonesia are largely drained. When precipitation is relatively low, the ground water table could fall below the peat and the DOC concentrations in the river would be reduced ${ }^{12}$. This might explain the exceptionally low DOC concentration in April 2013, which can be associated with low precipitation rates (Table 1). However, despite the low DOC concentration, $\mathrm{pCO}_{2}$ concentrations remained high pointing to an additional carbon source. This could have been a decaying plankton bloom favoured by the enhanced light availability due to the lower DOC concentrations. A similar situation might also explain the Lupar in 2013, where low DOC concentrations are associated with low precipitation rates, but relatively high $\mathrm{pCO}_{2}$ concentrations still occur. This indicates that the dampening effects of reduced carbon input from soil leaching on the $\mathrm{pCO}_{2}$ concentrations could be counterbalanced by input of $\mathrm{CO}_{2}$ from presumably plankton blooms, which reduces the temporal variability of $\mathrm{pCO}_{2}$ in the rivers during time characterized by extremely low DOC leaching.

River outgassing and DOC export. Quantification of both river outgassing and riverine DOC export sheds light on their flux ratio and consequently the share of river outgassing with respect to the carbon entering the freshwater system. $\mathrm{CO}_{2}$ emissions were calculated for all investigated rivers using equation 1 (Methods section) with their respective piston velocities and respective $\Delta \mathrm{pCO}_{2}$, which were based on their averaged $\mathrm{pCO}_{2}$ values (Table 1) and an atmospheric $\mathrm{CO}_{2}$ concentration of $390 \mu \mathrm{atm}$. Subsequently, these fluxes were multiplied by their respective river surface area (Methods section and Table 2) to calculate the flux per river. Riverine DOC exports were calculated by multiplying the DOC concentrations with the discharges, which were based on the averaged monthly precipitations (Table 1) and assuming an evapotranspiration of $38 \%$ (ref. 9). The resultant net water-air $\mathrm{CO}_{2}$ fluxes and riverine DOC exports are presented in Table 3. Note that both $\mathrm{CO}_{2}$ and DOC fluxes are shown in grams $10^{9} \mathrm{mth}^{-1}$. These results suggest that on average $53.3 \pm 6.5 \%$ of the organic carbon leached from soils is decomposed in the river and emitted as $\mathrm{CO}_{2}$ into the atmosphere. This percentage is based on monthly averages from six rivers, has a relatively small s.e. and is similar to the $45-60 \%$ that was reported as the global average in

Table 2 | River surface area.

\begin{tabular}{|c|c|c|c|c|c|}
\hline River & Length (km) & Width (m) & Catchment area $\left(\mathbf{k m}^{2}\right)$ & River area $\left(\mathrm{km}^{\mathbf{2}}\right)$ & River coverage (\%) \\
\hline Musi & 780 & 312 & 56,931 & 243 & 0.43 \\
\hline Batanghari & 678 & 374 & 44,890 & 269 & 0.60 \\
\hline Indragiri & 366 & 475 & 17,968 & 174 & 0.97 \\
\hline Siak & 447 & 182 & 10,423 & 81 & 0.78 \\
\hline Lupar* & 246 & 758 & 6,541 & 186 & 0.12 \\
\hline Saribas ${ }^{\star}$ & 176 & 444 & 2,149 & 78 & 0.26 \\
\hline \multicolumn{6}{|l|}{ Location $^{\dagger}$} \\
\hline Malaysia & - & - & 327,291 & 2,291 & 0.70 \\
\hline Indonesia & - & - & $1,919,317$ & 15,354 & 0.80 \\
\hline SE-Asia & - & - & $2,652,370$ & 20,688 & 0.78 \\
\hline
\end{tabular}


Table 3 | $\mathrm{CO}_{2}$ flux versus DOC export - river outgassing in percentage.

\begin{tabular}{|c|c|c|c|c|c|c|c|}
\hline River & $\Delta \mathrm{pCO}_{2}$ ( $\left.\mu \mathrm{atm}\right)$ & $\begin{array}{c}\mathrm{K}_{\mathrm{cO2}} \\
\left(\mathrm{cm} \mathrm{h}^{-1}\right)\end{array}$ & $\begin{array}{l}\text { River area } \\
\left(\mathbf{k m}^{2}\right)\end{array}$ & $\begin{array}{l}\text { Discharge } \\
\left(m^{3} s^{-1}\right)\end{array}$ & $\begin{array}{l}\text { DOC flux } \\
\text { (Gg mth }^{-1} \text { ) }\end{array}$ & $\begin{array}{c}\mathrm{CO}_{2} \text { flux } \\
\left(\mathrm{Gg} \mathrm{mth}^{-1}\right)\end{array}$ & $\begin{array}{c}\text { Outgassing } \\
\text { (\%) }\end{array}$ \\
\hline Musi & $3,926 \pm 928$ & $21.8 \pm 4.7$ & 243 & $3,054 \pm 254$ & $23.6 \pm 4.0$ & $55.8 \pm 23.3$ & $70.3 \pm 6.0$ \\
\hline Batanghari & $2,010 \pm 18$ & $21.8 \pm 4.7$ & 269 & $2,556 \pm 422$ & $26.0 \pm 6.1$ & $32.5 \pm 6.7$ & $55.6 \pm 0.7$ \\
\hline Indragiri & $5,387 \pm 527$ & $21.8 \pm 4.7$ & 174 & $1,184 \pm 313$ & $26.7 \pm 9.4$ & $54.2 \pm 14.2$ & $67.0 \pm 2.0$ \\
\hline Siak & $8,165 \pm 528$ & $22.0 \pm 4.7$ & 87 & $684 \pm 76$ & $39.6 \pm 9.7$ & $37.5 \pm 7.5$ & $48.6 \pm 1.1$ \\
\hline Lupar & $884 \pm 148$ & $26.5 \pm 9.3$ & 186 & $197 \pm 86$ & $0.92 \pm 0.8$ & $0.83 \pm 0.0$ & $47.4 \pm 21.0$ \\
\hline Saribas & $769 \pm 29$ & $17.0 \pm 13.6$ & 78 & $44 \pm 11$ & $0.44 \pm 0.1$ & $0.19 \pm 0.0$ & $30.6 \pm 5.6$ \\
\hline Average & & & & & & & $53.3 \pm 6.5$ \\
\hline
\end{tabular}

The error of the $\Delta \mathrm{pCO}_{2}$ is the s.e., the $\mathrm{K}_{\mathrm{co} 2}$ has the largest error from the mean, the discharge has the s.d. and the $\mathrm{DOC}$ flux, $\mathrm{CO}_{2}$ flux and outgassing errors are based on the best/worst case deviation, with the average having a s.e. Averaged and used values are in bold.
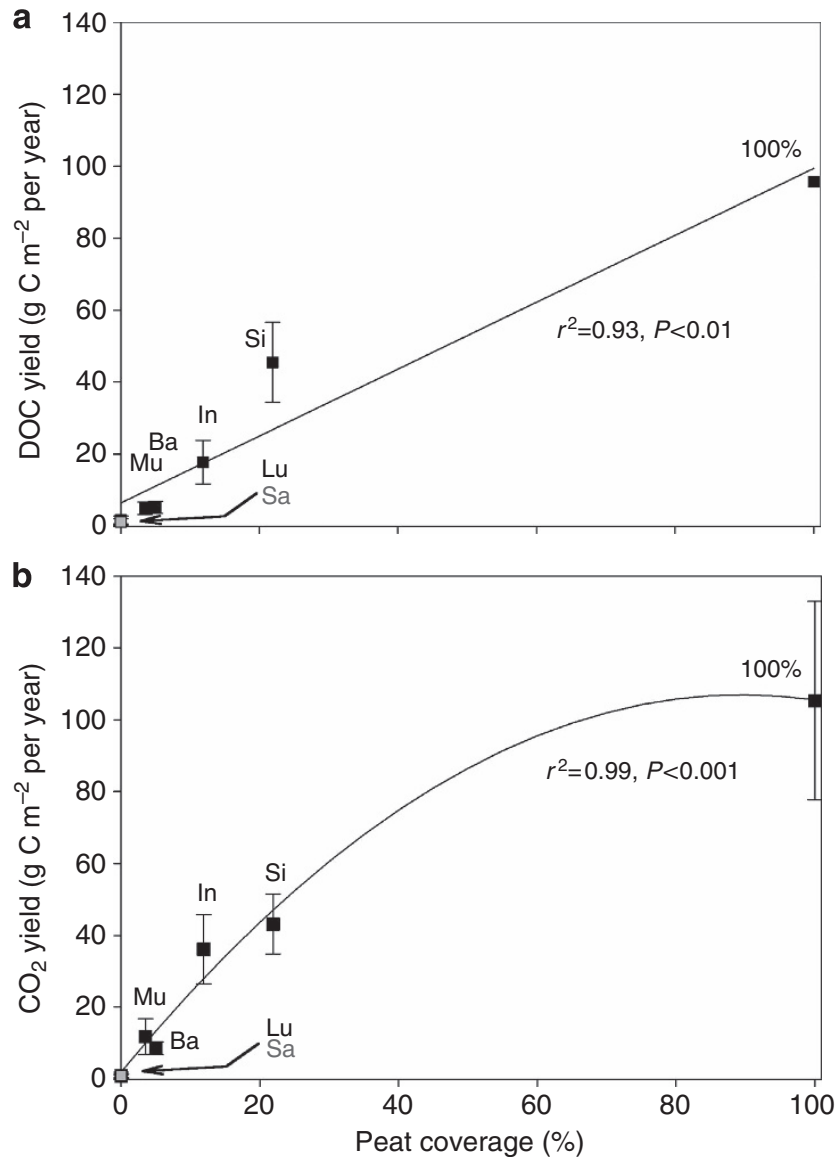

Figure 4 | Correlations of $\mathrm{DOC}$ yield and $\mathrm{CO}_{2}$ yield versus peat coverage. (a) Correlation of DOC yield versus peat coverage. (b) Correlation of $\mathrm{CO}_{2}$ yield versus peat coverage. The yields are shown in $\mathrm{g} \mathrm{Cm}^{-2}$ per year and the peat coverage in percentage. The peat coverage is expressed in percentage for each of the river catchments. The data points represent annual estimates at salinity $S=0$ in the rivers Musi, Batanghari, Indragiri and Siak in Sumatra, Indonesia. The salinity $S=0$ stations in the Lupar and Saribas rivers were located further upstream and outside of the peatland area. Consequently, their DOC concentrations and $\mathrm{CO}_{2}$ yields are representative for areas with $0 \%$ peat coverage. The Saribas, having only a seasonal data point, was excluded from this correlation, but is shown in grey. Note that the $\mathrm{CO}_{2}$ yield is expressed in grams of carbon per $\mathrm{m}^{2}$ of catchment area per year, not river area. Error bars represent the best and worst case scenario as a result of incorporating the s.d. of the $\mathrm{DOC}, \mathrm{pCO}_{2}$, piston velocity and temperature into the $\mathrm{DOC}$ and $\mathrm{CO}_{2}$ yield calculation.

the IPCC report, as mentioned before. Therefore we may assume that this percentage is also a representative value for river outgassing in SE-Asia.
$\mathrm{CO}_{2}$ fluxes and peat coverage in SE-Asia. As the data of this study is limited to a peat coverage of $21.9 \%$, the lateral DOC exports of $95.7 \mathrm{~g} \mathrm{Cm}^{-2}$ per year for disturbed peat and $61.7 \mathrm{~g} \mathrm{C} \mathrm{m}^{-2}$ per year for pristine peat, as determined in rivers on Borneo by Moore et al. ${ }^{9}$, were used to extend the data set to $100 \%$ peat coverage. Based on the fact that carbon leaching equals the sum of $\mathrm{CO}_{2}$ outgassing and riverine DOC export, this DOC export yield for $100 \%$ peat coverage was then converted to $\mathrm{CO}_{2}$ yield by assuming a river outgassing of $53.3 \pm 6.5 \%$ as found in the SE-Asian rivers. This results in $\mathrm{CO}_{2}$ yield for $100 \%$ peat coverage of $109.2 \mathrm{~g} \mathrm{C} \mathrm{m}^{-2}$ per year (disturbed) and $70.5 \mathrm{~g} \mathrm{C} \mathrm{m}^{-2}$ per year (pristine). Knowing that $90 \%$ of SE-Asian peatlands are disturbed and $10 \%$ pristine ${ }^{14}$, the $\mathrm{CO}_{2}$ yield for $100 \%$ peat coverage amounts to $105.3 \pm 27.6 \mathrm{~g} \mathrm{C} \mathrm{m}^{-2}$ per year. This ratio for disturbed and pristine is naturally accounted for in the in situ river measurements, assuming an even distribution.

The lateral DOC export of $95.7 \mathrm{~g} \mathrm{C} \mathrm{m}^{-2}$ per year and the net ecosystem $\mathrm{C}$ loss of disturbed peatlands of $433 \mathrm{~g} \mathrm{C} \mathrm{m}^{-2}$ per year derived from eddy covariance measurements ${ }^{15}$ together amount to $529 \mathrm{~g} \mathrm{C} \mathrm{m}^{-2}$ per year. Including the river outgassing flux of $109.2 \mathrm{~g} \mathrm{C} \mathrm{m}^{-2}$ per year, which accounts for a $20 \%$ increase, raises the net ecosystem $\mathrm{C}$ loss to a total of $638 \mathrm{~g} \mathrm{C} \mathrm{m}^{-2}$ per year (net $\mathrm{C}$ source).

The extent of peat coverage in the investigated rivers differs in each catchment and correlates with the $\mathrm{DOC}$ and $\mathrm{CO}_{2}$ yield, emphasizing the importance of peat as $\mathrm{DOC}$ and $\mathrm{CO}_{2}$ source (Fig. 4). The correlation found between peat coverage and $\mathrm{CO}_{2}$ yield shows that the correlation initially appears linear, but levels off after a peat coverage of $25 \%$, which indicates that the rate of $\mathrm{pCO}_{2}$ production declines with increasing peat coverage. This may be attributed to a limitation of bacterial production as a consequence of the low $\mathrm{pH}$ caused by the acidic organic environment $^{16}$ or oxygen depletion (this study, refs 10,16). Based on the peat coverages and respective $\mathrm{CO}_{2}$ yields, the annual $\mathrm{CO}_{2}$ fluxes were interpolated for Indonesia, Malaysia and SE-Asia (Table 4) using the regression. As a whole, SE-Asia releases $66.9 \pm 15.7 \mathrm{Tg} C$ per year through river outgassing, of which the majority is emitted by Indonesia with $53.9 \pm 12.4 \mathrm{Tg} \mathrm{C}$ per year. This is due to the fact that Indonesia holds $83 \%$ of SE-Asian peatlands in addition to a large land surface area. River outgassing in Malaysia amounts to $6.2 \pm 1.6 \mathrm{Tg} \mathrm{C}$ per year. Although no $\mathrm{CH}_{4}$ measurements were taken in the river, $\mathrm{CH}_{4}$ fluxes are not considered to play a significant role in river carbon emissions. This is supported by $\mathrm{CH}_{4}$ fluxes from the Saribas and Lupar estuaries, which emit $27 \pm 24 \mathrm{t} \mathrm{CH}_{4}-\mathrm{C}$ per year and $84 \pm 24 \mathrm{t}$ $\mathrm{CH}_{4}-\mathrm{C}$ per year, respectively, and are a minute fraction of the estuary $\mathrm{CO}_{2}$ fluxes $0.09 \pm 0.08$ and $0.31 \pm 0.09 \mathrm{TgC}$ per year (ref. 17). $\mathrm{CH}_{4}$ fluxes from peat soils are with $0.02 \mathrm{~g} \mathrm{C} \mathrm{m}^{-2}$ per year also much lower than those of peat soil $\mathrm{CO}_{2}$ fluxes $250 \mathrm{~g} \mathrm{C} \mathrm{m}^{-2}$ per year (ref. 18). 
Table 4 | $\mathrm{CO}_{2}$ yields and fluxes.

\begin{tabular}{|c|c|c|c|c|c|}
\hline Location & Peat coverage (\%) & Catchment area $\left(\mathrm{km}^{2}\right)$ & $\mathrm{CO}_{2}$ yield $\left(\mathrm{g} \mathrm{C} \mathrm{m}^{-2}\right.$ per year) & $\mathrm{CO}_{2}$ flux ( $\mathrm{Tg} \mathrm{C}$ per year) & Peat impact (\%) \\
\hline Musi & 3.5 & 56,931 & $11.8 \pm 5.0$ & $0.67 \pm 0.28$ & 83.5 \\
\hline Batanghari & 5.0 & 44,890 & $8.6 \pm 1.8$ & $0.39 \pm 0.08$ & 77.7 \\
\hline Indragiri & 11.9 & 17,968 & $36.1 \pm 9.7$ & $0.65 \pm 0.17$ & 95.1 \\
\hline Lupar* & 30.5 & 6,541 & $61.5 \pm 13.0$ & $0.30 \pm 0.04$ & 97.7 \\
\hline Saribas* & 35.5 & 2,149 & $69.0 \pm 14.6$ & $0.11 \pm 0.01$ & 98.1 \\
\hline Malaysia & 7.6 & 327,291 & $19.1 \pm 4.8$ & $6.2 \pm 1.6$ & 90.1 \\
\hline
\end{tabular}

The errors of the $\mathrm{CO}_{2}$ yield and flux represent the best/worst case deviation.

${ }^{\star}$ The Lupar and Saribas stations were located upstream from the peatland area; their data are therefore typical for a peat coverage of $0 \%$. With the $\mathrm{Lupar}_{\mathrm{pCO}} \mathrm{C}$ measurements at $0 \%$ peat coverage, the correlation between annual $\mathrm{CO}_{2}$ yield and peat coverage was derived (Fig. $4 \mathrm{~b}$ ). The Saribas, having only one (seasonal) data point, was excluded from this correlation, but is shown in grey in Fig. $4 \mathrm{~b}$. The correlation was then used to estimate the $\mathrm{CO}_{2}$ yields and fluxes of the Lupar and Saribas with respect to their peat coverages of 30.5 and 35.5 , respectively, in their catchments.

$\dagger$ SE-Asia is defined here as Malaysia, Indonesia, Brunei and Papua New Guinea ${ }^{27}$. Their peat coverages and catchment areas are derived from Hooijer et al. ${ }^{27}$ and Miettinen et al. ${ }^{28}$ Peat coverage and catchment areas of the rivers were derived using an ArcGIS relief model and FAO Soil map of the world (Methods section).

\begin{tabular}{|c|c|c|c|c|c|}
\hline $\begin{array}{l}\text { Row } \\
\text { No. }\end{array}$ & $\begin{array}{l}\text { Country covered } \\
\text { by COSCAT }\end{array}$ & $\begin{array}{l}\text { COSCAT } \\
\text { Code }\end{array}$ & $\begin{array}{c}\mathrm{pCO}_{2} \\
(\mu \mathrm{atm})\end{array}$ & $\begin{array}{c}\mathrm{K} \\
\left(\mathrm{cm} \mathrm{h}^{-1}\right)\end{array}$ & $\begin{array}{l}\mathrm{CO}_{2} \text { yield } \\
\left(\mathrm{g} \mathrm{C} \mathrm{m}^{-2}\right. \\
\text { per year) }\end{array}$ \\
\hline 1 & Malaysia/Brunei & 1,328 & 1,1760 & 39.58 & 148.10 \\
\hline 2 & Malaysia/Indonesia & 1,329 & 11,772 & 36.67 & 122.90 \\
\hline 3 & Malaysia/Indonesia & 1,335 & 7,404 & 65.83 & 174.00 \\
\hline 4 & Indonesia & 1,330 & 11,265 & 40.83 & 111.00 \\
\hline 5 & Indonesia & 1,333 & 458 & 58.33 & 0.20 \\
\hline 6 & Indonesia & 1,334 & 10,497 & 87.08 & 124.40 \\
\hline 7 & $\begin{array}{l}\text { Indonesia/Papua } \\
\text { New Guinea }\end{array}$ & 1,416 & 292 & 66.25 & -1.70 \\
\hline 8 & $\begin{array}{l}\text { Indonesia/Papua } \\
\text { New Guinea }\end{array}$ & 1,401 & 372 & 143.33 & -3.00 \\
\hline 9 & Papua New Guinea & 1,402 & 435 & 31.67 & 1.00 \\
\hline 10 & Papua New Guinea & 1,403 & 1,269 & 64.17 & 7.30 \\
\hline
\end{tabular}

Considering that the data is collected during the transitional stages during the year with respect to precipitation, the mean values represent a suitable yearly average. Although extreme events such as droughts or heavy rainfall have not been measured, their influence will not alter the estimated $\mathrm{CO}_{2}$ fluxes significantly. As discussed earlier, the effect of increased discharge due to high water saturated peatlands dilutes the DOC concentration, which dampens the effect of enhanced discharge $e^{11,19,20}$. Therefore a decrease is expected in DOC and hence $\mathrm{pCO}_{2}$ concentrations during extreme events in peatland areas. In nonpeat areas, enhanced precipitation will increase DOC leaching and hence, $\mathrm{DOC}$ and $\mathrm{pCO}_{2}$ concentrations in the river waters. However, as seen in Table 4, the impact of peat on the $\mathrm{CO}_{2}$ fluxes, wherein the impact is defined as the share of $\mathrm{CO}_{2}$ emissions from peatlands expressed in percentage, is much larger than that of non-peat areas. The regression indicates that non-peat areas have a $\mathrm{CO}_{2}$ yield of $2.0 \mathrm{~g} \mathrm{Cm}^{-2}$ per year and only contribute $7.1 \%$ (4.8 Tg per year) to the $\mathrm{CO}_{2}$ fluxes in SE-Asia, as opposed to $92.8 \%$ (62.1 Tg per year) from peatlands (Table 3). Assuming a case of heavy rainfall, wherein the $\mathrm{CO}_{2}$ yield would double to $4.0 \mathrm{~g} \mathrm{C} \mathrm{m}^{-2}$ per year, would increase the $\mathrm{CO}_{2}$ flux from non-peat areas to $9.6 \mathrm{Tg}$ per year, but would not significantly increase the total annual $\mathrm{CO}_{2}$ fluxes for SE-Asia. Additionally, the effect of the large peat impact and that $\mathrm{CO}_{2}$ fluxes from peatlands will decrease due to dilution from increased discharge, will outweigh the increased $\mathrm{CO}_{2}$ flux of non-peat areas, thereby maintaining a steady or even decreased $\mathrm{CO}_{2}$ flux during extreme rainfall. Therefore, our annual $\mathrm{CO}_{2}$ flux estimates can be assumed to be representative for SE-Asia, wherein fluctuations due to extreme events are accounted for in the error range.

Study comparison. For data comparison, the $\mathrm{CO}_{2}$ flux and piston velocity estimates of Raymond et al. ${ }^{6}$ were used, who have calculated global inland water- $\mathrm{CO}_{2}$ effluxes by means of a global set of calculated piston velocities, $\mathrm{pCO}_{2}$ values ${ }^{21}$ and COSCAT areas (Coastal Segmentation and related CATchments). These COSCAT areas are characterized by their coastal segment limits and length and by catchment characteristics, such as runoff direction and physiographic units ${ }^{22}$. Raymond et al. ${ }^{6}$ assigned an average piston velocity and an average $\mathrm{pCO}_{2}$ value to each of these COSCATs from which they estimated the $\mathrm{CO}_{2}$ yield per $\mathrm{m}^{2}$ land per year. Several of these COSCAT areas, 10 of which are relevant for our study area, overlap SE-Asia and are summarized in Table 5. Based on the COSCATs in Table 5 the $\mathrm{pCO}_{2}$, $\mathrm{K}_{\mathrm{CO} 2}$ and $\mathrm{CO}_{2}$ yield were averaged for Malaysia (row 1-3), Indonesia (row 2-8) and SE-Asia (row 1-10), after which the corresponding $\mathrm{CO}_{2}$ flux was calculated and compared with our data (Table 6).

In addition, an indirect comparison was made based on recent estimates by Lauerwald et al. ${ }^{7}$ (Table 6). Although no data is available for SE-Asia, they do provide estimates of $\mathrm{pCO}_{2}$ concentrations and piston velocities for the tropical zone $\left(<25^{\circ}\right)$, which we used to predict their $\mathrm{CO}_{2}$ fluxes in SE-Asia (Table 6), assuming a river surface coverage as determined in our study (Table 2).

The comparison of Raymond et al. ${ }^{6}$ with our data reveals that the $\mathrm{CO}_{2}$ flux estimates for Indonesia and SE-Asia by Raymond et al. ${ }^{6}$ are almost three times higher than those found in this study with $144.7 \mathrm{TgC}$ per year and $181.5 \mathrm{TgC}$ per year, respectively. The Malaysian estimate peaks almost eightfold with $48.8 \mathrm{TgC}$ per year. These overestimations were already anticipated by Raymond et $a l^{6}$ and are explained by the small number of calculated $\mathrm{CO}_{2}$ values they had available in these COSCATs. Moreover, compared with our findings, their piston velocities appear to be largely overestimated (Table 5) and are mainly responsible for the resulting $\mathrm{CO}_{2}$ flux overestimations of Raymond et al..$^{6}$. As for Lauerwald et al. ${ }^{7}$, their data for the tropical zone $\left(<25^{\circ}\right)$ include piston velocities similar to ours, but show $\mathrm{pCO}_{2}$ concentrations that are 21, 40 and $35 \%$ lower in Malaysia, Indonesia and SE-Asia, respectively, and result in lower $\mathrm{CO}_{2}$ emissions.

Explanatory arguments for moderate fluxes. The overall statement of this study conveys that SE-Asia is in fact not such a river $\mathrm{CO}_{2}$ outgassing hotspot as one could assume due to the 
Table 6 | Study comparison of averaged $\mathrm{pCO}_{2}$ concentrations, piston velocities, $\mathrm{CO}_{2}$ yields and estimated $\mathrm{CO}_{2}$ fluxes.

\begin{tabular}{|c|c|c|c|c|c|}
\hline Location & Study & $\mathrm{pCO}_{2}(\mu \mathrm{atm})$ & $K\left(\mathrm{~cm} \mathrm{~h}^{-1}\right)$ & $\mathrm{CO}_{2}$ yield $\left(\mathrm{g} \mathrm{C} \mathrm{m}^{-2}\right.$ per year) & $\mathrm{CO}_{2}$ flux ( $\mathrm{Tg} \mathrm{C}$ per year) \\
\hline \multirow[t]{3}{*}{ Malaysia } & Raymond et al. ${ }^{6}$ & $10,312 \pm 1781$ & $47.4 \pm 11.4$ & $148.33 \pm 18.1$ & $48.8 \pm 5.9$ \\
\hline & ${ }^{\star}$ Lauerwald et al. ${ }^{7}$ & $3,188 \pm 575$ & $24.6 \pm 2.9$ & $15.1 \pm 4.9$ & $4.9 \pm 1.6$ \\
\hline & †This study & $4,369 \pm 393$ & $21.8 \pm 11.5$ & $19.6 \pm 4.0$ & $6.2 \pm 1.6$ \\
\hline \multirow{3}{*}{ Indonesia } & Raymond et al. ${ }^{6}$ & $6,009 \pm 4554$ & $59.9 \pm 11.3$ & $75.4 \pm 30.5$ & $144.7 \pm 54.5$ \\
\hline & ${ }^{*}$ Lauerwald et al. ${ }^{7}$ & $3,188 \pm 575$ & $24.6 \pm 2.9$ & $17.3 \pm 5.6$ & $33.1 \pm 10.7$ \\
\hline & ${ }^{\dagger}$ This study & $5,535 \pm 498$ & $21.9 \pm 4.71$ & $26.6 \pm 4.6$ & $53.8 \pm 12.4$ \\
\hline \multirow[t]{3}{*}{ SE-Asia } & Raymond et al. ${ }^{6}$ & $5,552 \pm 3943$ & $63.4 \pm 19.6$ & $68.4 \pm 24.4$ & $181.5 \pm 64.8$ \\
\hline & ${ }^{\star}$ Lauerwald et al. ${ }^{7}$ & $3,188 \pm 575$ & $24.6 \pm 2.9$ & $14.4 \pm 5.4$ & $44.6 \pm 14.4$ \\
\hline & †This study & $5,155 \pm 464$ & $21.8 \pm 7.0$ & $24.5 \pm 4.4$ & $66.8 \pm 15.7$ \\
\hline
\end{tabular}

Studies include that of Raymond et al. ${ }^{6}$, Lauerwald et al. ${ }^{7}$ and this study. Errors indicate the s.e. (ref. 6), largest deviation from the mean (ref. 7 ) and best/worst case deviation (this study).

${ }^{\star} \mathrm{CO}_{2}$ yield and fluxes for Lauerwald et al. ${ }^{7}$ are estimated based on the river surface areas defined in our study (Table 2).

$\dagger$ Errors for $\mathrm{pCO}_{2}$ are based on the average s.e. of $9 \%$ as found for the studied rivers.

carbon-enriched peat soils (Table 4). Even temperate zones, with a $\mathrm{CO}_{2}$ yield of $18.5 \mathrm{~g} \mathrm{Cm}^{-2}$ per year (based on an average $\mathrm{CO}_{2}$ yield of $2370 \mathrm{~g} \mathrm{Cm}^{-2}$ per year (ref. 23) of river surface area, converted to $\mathrm{m}^{2}$ catchment area with a river coverage of $0.78 \%$ as estimated for SE-Asia) are close to the $\mathrm{CO}_{2}$ yield of $25.2 \mathrm{~g} \mathrm{Cm}^{-2}$ per year of SE-Asia. $\mathrm{CO}_{2}$ yields from other tropical river systems, such as the Amazon are much larger with $120 \pm 30 \mathrm{~g} \mathrm{Cm}^{-2}$ per year (ref. 24), and show that $\mathrm{CO}_{2}$ outgassing from SE-Asian rivers is rather moderate. The main reason for these moderate fluxes is the relatively short residence time ${ }^{10}$ of DOC in the river water due to the location of the peatlands near the coast, which are the main source of DOC. Limitation of bacterial production, as a consequence of the low $\mathrm{pH}$ caused by the acidic organic environment ${ }^{16}$, oxygen depletion (this study, refs 10,16 ), or the refractory nature of DOC (refs 10,25,26), potentially also contributes to the moderate $\mathrm{CO}_{2}$ fluxes as this decelerates decomposition, especially with increasing peat coverage.

In conclusion, this study shows that river outgassing fluxes in SE-Asia are in fact moderate and, in line with the 5th Assessment IPCC report, suggest that $\sim 53.3 \pm 6.5 \%$ of carbon entering the freshwater system is decomposed and emitted back to the atmosphere as $\mathrm{CO}_{2}$. Globally there are three tropical regions, of which Africa ${ }^{16}$ and Amazonia ${ }^{24}$ are significantly important contributors to the river outgassing budget. However, due to the fact that the main source of DOC is located near the coast, which further shortens the residence time of DOC in rivers, SE-Asia is a moderate emitter and global river outgassing estimates can therefore be scaled down. In future assessments, it needs to be considered that rivers function in a different way with respect to discharge, depending on residence time of DOC in the river and the soil type as it strongly affects the DOC leaching and consequently respiration and $\mathrm{CO}_{2}$ emission.

\footnotetext{
Methods

Study area. SE-Asian peatlands cover 27.1 million hectares and are located in the coastal plains of the islands of Sumatera, Borneo and Ian Jaya ${ }^{27}$. Tropical peatlands are particularly vulnerable to anthropogenic stressors, such as deforestation and drainage, which are used to convert peat swamp forests into cropland. Today, a large fraction of this peat is already found under oil palm plantations ${ }^{28}$ and only $10 \%$ remains undisturbed ${ }^{14}$. The investigated rivers in Sumatra, Indonesia, are the Musi, Batanghari, Indragiri and Siak. All four rivers originate from the Barisan Mountains with a short steep descent and continue to flow towards the Malacca Strait. Towards the river mouths, the rivers cut through peatland areas which scatter the low-lying areas along the northern coast and are subject to leaching of organic matter ${ }^{29}$. The Siak is a typical black-water river ${ }^{30}$; its brown colour is derived from dissolved organic matter leached from adjacent disturbed peatlands, which cover $21.9 \%$ of its catchment area. The Indragiri, Batanghari and Musi have a peat coverage of $11.9,5.0$ and $3.5 \%$, respectively ${ }^{31}$. The thickness of the Sumatran peatlands varies between 2 and $10 \mathrm{~m}$ (ref. 27). Malaysia has $\sim 2$ million hectares of peatlands. Sarawak on the island of Borneo holds the largest share of Malaysia's peatlands, most of which used to be forested ${ }^{32}$. The two rivers Lupar and Saribas in
} Sarawak enclose a peninsula with protected peat swamp forest that has a peat thickness of up to $10 \mathrm{~m}$ (ref. 33). The estimated peat coverage for the Lupar basin is $30.5 \%$ and $35.5 \%$ for the Saribas catchment ${ }^{34}$.

SE-Asia is subject to the Malaysian-Australian monsoon as a result of the meridional variation of the intertropical convergence zone. During the wet season from October to April, northern air currents laden with moisture from Asia bring heavy rains to the southeastern parts, whereas southern dry air currents from Australia dominate during the dry season from May to September ${ }^{35}$. Precipitation in Pekanbaru, central Sumatra, ranges from $123 \mathrm{~mm}$ in July to $312 \mathrm{~mm}$ in November, with an annual sum of 2,696 mm (ref. 36). Rainfall in Kuching, Sarawak, Malaysia, is even higher and ranges from $196 \mathrm{~mm}$ in June to $675 \mathrm{~mm}$ in January ${ }^{37}$ with an annual sum of $4,616 \mathrm{~mm}$.

Expeditions. In this study, data is considered from a total of five expeditions, three of which took place in Sumatra (October 2009, October 2012 and April 2013), and two in Sarawak (June 2013 and March 2014). In October 2009, 72 sampling stations were made and focused mainly on the Siak river and continued along the coast, passing the other rivers to the Musi. In October 2012, the expedition stretched from the Musi river to the Batanghari river with a total of 32 sampling stations. In April 2013 the expedition started in the Musi river going northwest along the other rivers and back via the outer coastal regions, covering a total of 57 sampling stations. In Sarawak, 21 sampling stations were made along the Lupar and Saribas rivers and their estuaries in June 2013 and 26 stations in March 2014. The locations of the river sampling stations at salinity zero are shown on the map in Fig. 1 (ref. 38).

Sampling methods. In Sumatra, $\mathrm{pH}$, salinity, temperature, dissolved oxygen and $\mathrm{pCO}_{2}$ were measured continuously by means of underway instruments. All sensors were arranged in a flow through system and supplied with surface water from an approximate depth of $1 \mathrm{~m}$. Salinity was measured using a Seabird SBE 45 Micro TSG sensor. Temperature and $\mathrm{pH}$ were measured with a Meinsberg EGA 140 SMEK with integrated temperature sensor. Oxygen measurements were conducted with an Aanderaa Optode 3835. $\mathrm{pCO}_{2}$ was measured with two devices: the Li-Cor $7,000 \mathrm{pCO}_{2}$ analyzer (October 2009 and October 2012) and the Contros HydroC $\mathrm{CO}_{2}$ Flow Through sensor (October 2012 and April 2013). Before the expeditions both devices were calibrated, of which the Contros at 100, 448 and 800 p.p.m. The Li-Cor 7,000 analyzer was calibrated with certificated NOAA reference gases (\#CB08923 with 359.83 p.p.m., \#CA06265 with 1,021.94 p.p.m. and another certified calibration gas with 8,000 p.p.m. $\mathrm{CO}_{2}$ ).

In addition to the continuous measurements, water samples were collected at each station using a Niskin bottle at an approximate depth of $1.5 \mathrm{~m}$. DOC samples were filtered $(0.45 \mu \mathrm{m})$, stored in $60 \mathrm{ml}$ high-density polyethylene (HDPC) bottles and acidified with phosphoric acid (20\%) to a $\mathrm{pH}$-value of 2 . After a total storage time during and after the expeditions of maximum 3 weeks, DOC samples were analysed upon arrival in the laboratory in Bremen, Germany, with a Dohrmann DC-190 Total Organic Carbon Analyzer. The samples were combusted at $680^{\circ} \mathrm{C}$ within a quartz column, filled with $\mathrm{Al}_{2} \mathrm{O}_{3}$-balls covered with platinum. The released $\mathrm{CO}_{2}$ was purified, dried and measured by a non-dispersive infrared detection system. The relative s.d. for the method was $\pm 2 \%$.

In Sarawak, $\mathrm{pCO}_{2}$ was measured with an in situ FTIR analyzer ${ }^{39}$, using a Weiss equilibrator ${ }^{40}$. In the headwater region, which was not accessible by boat, a Li-820 $\mathrm{CO}_{2}$ analyzer was used together with headspace equilibration in a 10-1 water bottle (June 2013) and a 600-ml conical flask (March 2014). The FTIR and the Li-820 were calibrated with the same set of secondary standards, ranging from 380 to 10,000 p.p.m. $\mathrm{CO}_{2}$. Samples were taken for DOC following the same procedure as described above. Dissolved oxygen, $\mathrm{pH}$ and conductivity were measured using a WTW Multi 3420 with an FDO 925 oxygen sensor, a SenTix 940 IDS pH sensor and a TetraCon 925 conductivity sensor. Salinity was calculated from conductivity using the equations by Bennet ${ }^{41}$. Floating chamber measurements were performed to determine the $\mathrm{CO}_{2}$ flux. The chamber had a volume of 8.71 and a surface area of 
$0.05 \mathrm{~m}^{2}$. The $\mathrm{CO}_{2}$ flux was determined from the increase of the $\mathrm{CO}_{2}$ mixing ratio over time, which was monitored with the Li-820.

Calibration experiment. To calibrate the Contros river measurements, a $\mathrm{CO}_{2}$ calibration experiment was conducted during which different concentrations of $\mathrm{CO}_{2}$ gas were delivered using a gas mixing system. Before the calibration with water measurements, the gas concentrations delivered by the gas mixing system were controlled by the mixing system regulator, the Li-Cor 7000, the Li-820 and the cavity ring-down spectrometer (Picarro G2201-i) in a range from circa 500 to 6,000 p.p.m. (Supplementary Fig. 1a). The gas was then used to calibrate freshwater in a range of 1,500-5,500 p.p.m. that was pumped into the Li-Cor 7,000 equilibrator and the Contros sensor. The measured $\mathrm{pCO}_{2}$ concentrations were correlated and the regression equation (Supplementary Fig. 1b) was used to calibrate the Contros river data measured during the expedition in 2013.

$\mathbf{C O}_{\mathbf{2}}$ flux calculation. $\mathrm{CO}_{2}$ fluxes $(\mathrm{F})$ were calculated from $\mathrm{pCO}_{2}$ using:

$$
\mathrm{F}=\mathrm{K}_{\mathrm{co}_{2}} \times \mathrm{K}_{0} \times \Delta \mathrm{pCO}_{2}
$$

where $\mathrm{K}_{\mathrm{CO} 2}$ is the $\mathrm{CO}_{2}$ piston velocity $\left(\mathrm{cm} \mathrm{h}^{-1}\right), \mathrm{K}_{0}$ the solubility coefficient of $\mathrm{CO}_{2}$ in seawater ${ }^{42}$ and $\Delta \mathrm{pCO}_{2}$ ( $\left.\mu \mathrm{atm}\right)$ is the sea-air $\mathrm{pCO}_{2}$ difference.

Usually, the piston velocity is poorly constrained and spatially and temporally highly variable. Raymond and $\mathrm{Cole}^{43}$ have pointed out that flux estimates can easily be altered by considerable amounts depending on the choice of the piston velocity. Meanwhile, the ways to determine the piston velocity are multifarious. Relationships with wind speed, hydraulic characteristics ${ }^{44}$, in situ measurements using floating chambers ${ }^{45,46}$ or dual tracer techniques ${ }^{47}$ are commonly used. Empirical models neglect small-scale fluctuations and allow for estimates on larger scales. These models relate environmental parameters to the piston velocity. In coastal systems and the ocean, this is mostly wind speed ${ }^{48}$. In rivers, stream velocity, stream slope, depth, discharge and bedrock roughness have been identified as the main drivers of in-stream turbulence and consequently the piston velocity ${ }^{44}$. In this study, floating chambers were used to determine piston velocities. The performance of floating chambers is a matter of debate, where both over- and underestimations occur due to artificial turbulence and shielding of wind, respectively, are suggested. On the other hand, sometimes, a relatively good agreement between floating chamber measurements and other techniques is reported ${ }^{49}$. The floating chamber measurements conducted on the Lupar and Saribas river are described in detail in Müller et al. ${ }^{50}$. There, we also discuss potential biases. The piston velocities of the Lupar and Saribas rivers were determined with nine floating chamber measurements and are averaged at $26.5 \pm 9.3 \mathrm{~cm} \mathrm{~h}^{-1}$ and $17.0 \pm 13.6 \mathrm{~cm} \mathrm{~h}^{-1}$, respectively, after normalization to a $\mathrm{CO}_{2}$ Schmidt number of $360\left(30^{\circ} \mathrm{C}\right)^{44}$. For the Siak river, Rixen et al. ${ }^{10}$ derived a similar piston velocity of $22.0 \mathrm{~cm} \mathrm{~h}^{-1}$ using an oxygen balance model. Given that these rivers have piston velocities of a similar range, despite having different catchment sizes ${ }^{51}$ and slopes, we believe that they provide a good representation of the piston velocities in the Indragiri, Batanghari and Musi, Therefore, their average of $21.8 \pm 4.7 \mathrm{~cm} \mathrm{~h}^{-1}$ is used to calculate the fluxes in these three rivers, whereas the river-specific piston velocities were applied accordingly in the other rivers.

Peat coverages. Catchment area was calculated using a relief model of the Earth's surface in ArcGIS 9.3 with the ArcHydro extension. Digital Elevation Data (DEM) such as the SRTM90mDEM can be obtained from the web site of the Consortium for Spatial Information (CGIAR-CSI) of the Consultative Group for International Agricultural Research (CGIAR, http://www.cgiar-csi.org) ${ }^{52}$. The SRTM90mDEM has a spatial resolution of $90 \mathrm{~m}$ at the equator and was originally produced in the framework of the NASA Shuttle Radar Topographic Mission (SRTM). Peat coverage (\%) for each catchment was estimated using a combination of the FAO Soil Map of the World ${ }^{31}$ and the catchment area derived from the ArcGIS DEM model.

The peat coverage for Malaysia, Indonesia and SE-Asia was derived from Hooijer et al..$^{27}$, who based their peat coverage percentages for these areas on field surveys provided by Wetlands International and the FAO Digital Soil Map of the World ${ }^{31}$, as well as Miettinen $e t$ al. $^{28}$, who used satellite images from as recent as 2010. However, data of Miettinen et al. ${ }^{28}$ only covers Malaysia, Sumatra and Kalimantan, whereas that of Hooijer et al. ${ }^{27}$ covers entire SE-Asia. Therefore, peat coverage for Malaysia, Indonesia and SE-Asia is based on the combination of Hooijer et al..$^{27}$ and Miettinen $e t a .^{28}$, wherein the most recent data was integrated where possible.

River surface coverage. For all six rivers, surface area estimation has been conducted based on the length and width of their primary course and main tributaries. Length was estimated using HydroSheds stream lines and Google Earth was used to estimate width along multiple sections in the primary course and main tributaries for each river. River area (\%) was calculated based on the share of river surface area with respect to the catchment area. River coverages for Malaysia, Indonesia and SE-Asia are derived from the average $\mathrm{pCO}_{2}$, piston velocity and $\mathrm{CO}_{2}$ yield found for these locations (Table 6). The results are summarized in Table 2.
Uncertainty estimates. The errors ${ }^{53}$ associated with the averaged parameter per expedition are presented as the s.d. The errors of the averaged parameter per river are calculated as the s.e. where possible; otherwise the error is presented as the deviation of the two averages from the mean. Throughout the calculations of the $\mathrm{CO}_{2}$ yield and fluxes, the s.e. as derived from the averages were integrated. Therefore, the errors of the $\mathrm{CO}_{2}$ yields and fluxes are representative for the best and worst case scenarios, named as the best/worst case deviation.

\section{References}

1. Regnier, P. et al. Anthropogenic perturbation of the carbon fluxes from land to ocean. Nat. Geosci. 6, 597-607 (2013).

2. Battin, T. J. et al. The boundless carbon cycle. Nat. Geosci. 2, 598-600 (2009).

3. Cole, J. J. et al. Plumbing the Global carbon cycle: integrating inland waters into the terrestrial carbon budget. Ecosystems 10, 172-185 (2007).

4. Tranvik, L. J. et al. Lakes and reservoirs as regulators of carbon cycling and climate. Limnol. Oceanogr. 54, 2298-2314 (2009).

5. Ciais, P. et al.Carbon and Other Biogeochemical Cycles. In: Climate Change 2013: The Physical Science Basis. Contribution of Working Group I to the Fifth Assessment Report of the Intergovernmental Panel on Climate Change. (eds Stocker, T. F. et al.) (Cambridge University Press, 2013).

6. Raymond, P. A. et al. Global carbon dioxide emissions from inland waters. Nature 503, 355-359 (2013).

7. Lauerwald, R., Laruelle, G. G., Hartmann, J., Ciais, P. \& Regnier, P. A. G. Spatial patterns in $\mathrm{CO} 2$ evasion from the global river network. Glob. Biogeochem. Cycles 29, 1-21 (2015).

8. Page, S. E., Rieley, J. O. \& Banks, C. J. Global and regional importance of the tropical peatland carbon pool. Glob. Chang. Biol. 17, 798-818 (2011).

9. Moore, S. et al. Deep instability of deforested tropical peatlands revealed by fluvial organic carbon fluxes. Nature 493, 660-663 (2013).

10. Rixen, T. et al. The Siak, a tropical black water river in central Sumatra on the verge of anoxia. Biogeochemistry 90, 129-140 (2008).

11. Clark, J. M., Lane, S. N., Chapman, P. J. \& Adamson, J. K. Link between DOC in near surface peat and stream water in an upland catchment. Sci. Total Environ. 404, 308-315 (2008).

12. Moore, T. R. \& Jackson, R. J. Dynamics of dissolved organic carbon in forested and disturbed catchments, Westland, New Zealand: 2. Larry River. Water Resour. Res. 25, 1331 (1989).

13. Schiff, S. et al. Precambrian shield wetlands: hydrologic control of the sources and export of dissolved organic matter. Clim. Change 40, 167-188 (1998).

14. Miettinen, J. \& Liew, S. C. Degradation and development of peatlands in Peninsular Malaysia and in the islands of Sumatra and Borneo since 1990. Land Degrad. Dev. 21, 285-296 (2010).

15. Hirano, T. et al. Carbon dioxide balance of a tropical peat swamp forest in Kalimantan, Indonesia. Glob. Chang. Biol. 13, 412-425 (2007).

16. Borges, A. V. et al. Globally significant greenhouse-gas emissions from African inland waters. Nat. Geosci. 8, 637-642 (2015).

17. Müller, D. Water-atmosphere greenhouse gas exchange measurements using FTIR spectrometry. 75-100 (2015).

18. Couwenberg, J., Dommain, R. \& Joosten, H. Greenhouse gas fluxes from tropical peatlands in south-east Asia. Glob. Chang. Biol. 16, 1715-1732 (2010).

19. Clark, J. M., Lane, S. N., Chapman, P. J. \& Adamson, J. K. Export of dissolved organic carbon from an upland peatland during storm events: implications for flux estimates. J. Hydrol. 347, 438-447 (2007).

20. Worrall, F., Burt, T. P. \& Adamson, J. The rate of and controls upon DOC loss in a peat catchment. J. Hydrol. 321, 311-325 (2006).

21. Hartmann, J., Lauerwald, R., Moosdorf, N., Amann, T. \& Weiss, A. GLORICH: global river and estuary chemical database. ASLO (2011).

22. Meybeck, M., Dürr, H. \& Vörösmarty, C. Global coastal segmentation and its river catchment contributors: a new look at land-ocean linkage. Glob. Biogeochem. Cycles 20, GB1S90 (2006).

23. Butman, D. \& Raymond, P. A. Significant efflux of carbon dioxide from streams and rivers in the United States. Nat. Geosci. 4, 839-842 (2011).

24. Richey, J. E., Melack, J. M., Aufdenkampe, A. K., Ballester, V. M. \& Hess, L. L. Outgassing from Amazonian rivers and wetlands as a large tropical source of atmospheric $\mathrm{CO}_{2}$. Nature 416, 617-620 (2002).

25. Alkhatib, M., Jennerjahn, T. C. \& Samiaji, J. Biogeochemistry of the Dumai River estuary, Sumatra, Indonesia, a tropical black-water river. Limnol. Oceanogr. 52, 2410-2417 (2007).

26. Castillo, M. M., Kling, G. W. \& Allan, J. D. Bottom-up controls on bacterial production in tropical lowland rivers. Limnol. Oceanogr. 48, 1466-1475 (2003)

27. Hooijer, A., Silvius, M., Wösten, H. \& Page, S. E. PEAT- $\mathrm{CO}_{2}$, Assessment of $\mathrm{CO}_{2}$ emissions from drained peatlands in SE Asia. Delft Hydraulics report Q3943 (2006).

28. Miettinen, J. et al. Historical analysis and projection of oil palm plantation expansion on peatland in Southeast Asia. Int. Counc. Clean Transp. 22 (2012)

29. Baum, A. Tropical blackwater biogeochemistry: The Siak River in Central Sumatra, Indonesia. 69-81 (2008). 
30. Baum, A., Rixen, T. \& Samiaji, J. Relevance of peat draining rivers in central Sumatra for the riverine input of dissolved organic carbon into the ocean. Estuar. Coast. Shelf Sci. 73, 563-570 (2007).

31. FAO/UNESCO. Digital soil map of the world and derived soil properties. (2004).

32. Joosten, H., Tapio-Biström, M.-L. \& Tol, S. Peatlands - Guidance for climate change mitigation by conservation, rehabilitation and sustainable use. Mitigation of Climate Change in Agriculture Series 5. Proc. Soil Sci. Conf. (Malaysia, 2012)

33. Melling, L., Joo, G. K., Uyo, L. J., Sayok, A. \& Hatano, R. Biophysical characteristics of tropical peatland. Proc. Soil Sci. Conf. Malaysia 1917, 1-11 2007.

34. Nachtergaele, F., Velthuizen, H., Van \& Verelst, L. Harmonized world soil database. Food Agric. 43 (2008).

35. Gentilli, J., Smith, P. J. \& Krishnamurti, T. N. Malaysian-Australian monsoon. Encycl. Br. (2014) at www.britannica.com/science/Malaysian-Australianmonsoon.

36. Schwarz, T. Climate-Data. (2014) at en.climate-data.org.

37. Schneider, U. et al. GPCC monitoring product: near real-time monthly land-surface precipitation from rain-gauges based on SYNOP and CLIMAT data. (2011)

38. Wessel, P. \& Smith, W. H. F. New, improved version of the Generic Mapping Tools released. EOS Trans. AGU 79, 579 (1998).

39. Griffith, D. W. T. et al. A Fourier transform infrared trace gas and isotope analyser for atmospheric applications. Atmos. Meas. Tech. 5, 2481-2498 (2012).

40. Johnson, J. E. Evaluation of a seawater equilibrator for shipboard analysis of dissolved oceanic trace gases. Anal. Chim. Acta 395, 119-132 (1999).

41. Bennett, A. S. Conversion of in situ measurements of conductivity to salinity. Deep Sea Res. Oceanogr. Abstr. 23, 157-165 (1976).

42. Weiss, R. F. Carbon dioxide in water and seawater: the solubility of a non-ideal gas. Mar. Chem. 2, 203-215 (1974).

43. Raymond, P. A. \& Cole, J. J. Technical notes and comments gas exchange in rivers and estuaries: choosing a gas transfer velocity. Estuaries 24, 312-317 (2001).

44. Raymond, P. A. et al. Scaling the gas transfer velocity and hydraulic geometry in streams and small rivers. Limnol. Oceanogr. Fluids Environ. 2, 41-53 (2012).

45. Striegl, R. G., Dornblaser, M. M., McDonald, C. P., Rover, J. R. \& Stets, E. G. Carbon dioxide and methane emissions from the Yukon River system. Glob. Biogeochem. Cycles 26, GB0E05 (2012).

46. Alin, S. R. et al. Physical controls on carbon dioxide transfer velocity and flux in low-gradient river systems and implications for regional carbonudgets. J. Geophys. Res. Biogeosci. 116, G01009 (2011).

47. Ho, D. T., Schlosser, P. \& Orton, P. M. On factors controlling air-water gas exchange in a large tidal river. Estuar. Coasts 34, 1103-1116 (2011).

48. Wanninkhof, R. Relationship between wind speed and gas exchange over the ocean. J. Geophys. Res. Ocean 97, 7373-7382 (1992).

49. Huotari, J. S., Haapanala, J., Pumpanen, T., Vesala, T. \& Ojala, A. Efficient gas exchange between a boreal river and the atmosphere. Geophys. Res. Lett. 40, 5683-5686 (2013).

50. Müller, D. et al. Fate of peat-derived carbon and associated $\mathrm{CO}_{2}$ and $\mathrm{CO}$ emissions from two Southeast Asian estuaries. Biogeosci. Discuss 12, 8299-8340 (2015).
51. Milliman, J. D. \& Farnsworth, K. L. River Discharge To The Coastal Ocean: A Global Synthesis (Cambridge University Press, 2011).

52. Reuter, H. I., Nelson, A. \& Jarvis, A. An evaluation of void filling interpolation methods for SRTM data. Int. J. Geogr. Inf. Sci. 21, 983-1008 (2009).

53. Van Rossum, G. Python language reference, version 2.7. (2007).

54. DWD Global Precipitation Climatology Centre (GPCC). http://kunden.dwd.de/ GPCC/Visualizer (2015).

55. Schneider, U., Becker, A., Ziese, M. \& Rudolf, B. Global precipitation analysis products of the GPCC. Internet Publication 1-13 (2015). ftp://ftp-anon.dwd.de/ pub/data/gpcc/PDF/GPCC_intro_products_2008.pdf.

\section{Acknowledgements}

We would like to thank all scientists and students from the University of Pekanbaru for the fieldwork assistance and the captain and crew of the Matahari-ku ship for their support. We also want to thank the scientists and students from the University of Kuching. Maps were drawn using the Generic Mapping Tools and calculations were executed with Python software, version 2.7 (ref. 53). We are also grateful to the Federal German Ministry of Education, Science, Research and Technology (BMBF, Bonn Grant No. 03F0642-ZMT). Furthermore, we would like to thank the Sarawak Biodiversity Center for permission to conduct research in Sarawak waters (Permit No. SBC-RA-0097MM). We are grateful to Moritz Müller for his contribution to this manuscript. We thank Nastassia Denis and all scientists and students from Swinburne University and the University of Malaysia Sarawak who were involved in the sampling campaigns in Malaysia, as well as Lukas Chin and the crewmembers of the SeaWonder for their support. Dr Aazani Mujahid (University of Malaysia Sarawak) is acknowledged for her comprehensive organizational support. The expeditions to Malaysia were funded by the University of Bremen through the 'exploratory project' Moritz Müller.

\section{Author contributions}

T.R. and W.S.P. designed the study. D.M., T.W. and M.M. performed the Sarawak field data collection and D.M. performed the analysis. A.B. performed the Sumatra field data collection and analysis in 2009 and F.W. in 2012 and 2013. F.W. led the writing of the paper. All authors discussed results and commented on the manuscript.

\section{Additional information}

Supplementary Information accompanies this paper at http://www.nature.com/ naturecommunications

Competing financial interests: The authors declare no competing financial interests.

Reprints and permission information is available online at http://npg.nature.com/ reprintsandpermissions/

How to cite this article: Wit, F. et al. The impact of disturbed peatlands on river outgassing in Southeast Asia. Nat. Commun. 6:10155 doi: 10.1038/ncomms10155 (2015)

(c) (i) This work is licensed under a Creative Commons Attribution 4.0 International License. The images or other third party material in this article are included in the article's Creative Commons license, unless indicated otherwise in the credit line; if the material is not included under the Creative Commons license, users will need to obtain permission from the license holder to reproduce the material. To view a copy of this license, visit http://creativecommons.org/licenses/by/4.0/ 